\title{
HUBUNGAN KESEIMBANGAN DAN KELINCAHAN TERHADAP KETERAMPILAN SEPAK SILA PEMAIN SEPAKTAKRAW SMP NEGERI 2 BATANG ANAI
}

\author{
Zulman $^{1}$, Ali Umar ${ }^{2}$, Atradinal ${ }^{3}$ \\ ${ }^{1}$ Program Studi Pendidikan Jasmani Kesehatan dan Rekreasi, Fakultas Ilmu \\ Keolahragaan, Universitas Negeri Padang, Jalan Prof. DR. Hamka Air Tawar \\ Barat, Padang, 25132, Indonesia \\ ${ }^{2}$ Program Studi Pendidikan Jasmani Kesehatan dan Rekreasi, Fakultas Ilmu \\ Keolahragaan, Universitas Negeri Padang, Jalan Prof. DR. Hamka Air Tawar \\ Barat, Padang, 25132, Indonesia
}

$\underline{\text { zulman@fik.unp.ac.id }}{ }^{1}, \underline{\text { aliumar@fik.unp.ac.id }^{2}}, \underline{\text { atradinal@ }^{\prime} \text { fik.unp.ac.id }}{ }^{1}$

\begin{abstract}
Abstrak
Masalah penelitian adalah rendahnya keterampilan Sepak Sila pemain Sepaktakraw SMP Negeri 2 Batang Anai. Hal ini diduga dipengaruhi oleh keseimbangan dan kelincahan yang dimiliki pemain. Tujuan penelitian adalah untuk mengetahui hubungan keseimbangan dan kelincahan terhadap keterampilan Sepak Sila Pemain Sepaktakraw SMP Negeri 2 Batang Anai.

Jenis penelitian adalah korelasi, dengan populasi pemain Sepaktakraw SMP Negeri 2 Batang Anai sebanyak 15 orang. Penarikan sampel menggunakan teknik total sampling yang mana seluruh populasi 15 orang dijadikan sampel. Pengumpulan data penelitian keseimbangan menggunakan tes keseimbangan dengan tes berdiri dengan satu kaki dengan mengembangkan kedua tangan, dan kelincahan menggunakan tes suthle run (lari bolak-balik), keterampilan Sepak Sila, dengan melakukan Sepak Sila pemain diberi kesempatan melakukanya selama 60 detik. Data diolah menggunakan rumus korelasi product moment.

Hasil penelitian ditemukan 1) Terdapat hubungan yang signifikan antara keseimbangan dengan keterampilan Sepak Sila dalam Sepaktakraw pemain SMP Negeri 2 Batang Anai dengan $t_{\text {hitung }}(3.240)>t_{\text {tabel }}(1.771)$, 2) Tidak terdapat hubungan yang signifikan antara kelincahan dengan keterampilan Sepak Sila dalam Sepaktakraw pemain SMP Negeri 2 Batang Anai dengan $t_{\text {hitung }}(0.371)<t_{\text {tabel }}(1.771)$, 3) Terdapat hubungan yang signifikan antara keseimbangan dan kelincahan secara bersama-sama terhadap keterampilan Sepak Sila dalam Sepaktakraw dengan $F_{\text {hitung }}(5.86)>F_{\text {tabel }}(3.88)$ dilihat dari pemain Sepaktakraw SMP Negeri 2 Batang Anai.

Kata Kunci : Keseimbangan, Kelincahan Dan Keterampilan Sepak Sila

\section{PENDAHULUAN}

Olahraga merupakan kegiatan yang bermanfaat dan dapat meningkatkan kesegaran jasmani. Selain untuk memupuk watak, kepribadian, disiplin, sportifitas, olahraga juga dapat meningkatkan kemampuan daya pikir serta perkembangan prestasi. Secara fisiologi olahraga dapat meningkatkan fungsi organ

tubuh sistem pernafasan, koordinasi syaraf dan pengaruh sosial serta rohani.

Pencapaian prestasi dalam olahraga bukanlah pekerjaan yang mudah dibutuhkan usaha yang maksimal untuk mencapai prestasi tersebut. Oleh karena itu dalam olahraga perlu pembinaan dan pengembangan olahraga secara terencana, berjenjang dan berkelanjutan.
\end{abstract}


Peningkatan kompetensi sebagai usaha untuk mencapai prestasi perlu didukung melalui ilmu pengetahuan dan teknologi keolahragaan suatu bangsa.

Sepaktakraw merupakan salah satu olahraga permainan yang bermanfaat dan berkembang di Sumatra Barat. Olahraga tersebut banyak digemari dari kalangan pelajar sampai generasi tua. Hal tersebut dapat dilihat mulai bermunculan klub-klub Sepaktakraw. Termasuk pemain Sepaktakraw SMPN 2 Batang Anai. Melalui klub-klub tersebut dilakukan pembinaan dan selanjutnya diadakan seleksi bagi yang berbakat.

Untuk dapat bermain Sepaktakraw dengan baik, seseorang harus dapat menguasai kemampuan dasar bermain Sepaktakraw. Penguasaan terhadap teknik dasar perlu dimiliki oleh setiap pemain Sepaktakraw, apalagi teknik dasar merupakan teknik yang sangat mendasar dalam bermain Sepaktakraw seperti diuraikan Asril (1994) sebagai berikut:

Penguasaan teknik dasar permainan Sepaktakraw sangat penting mengingat permainan Sepaktakraw adalah permainan yang cepat. Sehingga penguasaan teknik yang tidak sempurna akan memungkinkan timbulnya kesalahan-kesalahan teknik yang lebih besar dan penguasaan teknik yang tinggi hanya dimungkinkan kalau penguasaan teknik dasar dalam bermain Sepaktakraw cukup sempurna.

Berdasarkan kutipan di atas pengusaan teknik dalam permainan Sepaktakraw adalah teknik dasar dan teknik khusus. Upaya meningkatkan keterampilan dasar bermain Sepaktakraw, seorang pemain berusaha meningkatkan teknik dasar dan dalam permainan Sepaktakraw secara sempurna.

Sepak Sila adalah suatau teknik dasar yang penting dan utama dalam permainan Sepaktakraw, karena kemampuan penguasaan Sepak Sila yang baik akan memudahkan seseorang dalam mengontrol, mengumpan bola, menerima bola dan menahan serangan lawan dan servis.

Berdasarkan pemantauan peneliti dari fenomena di lapangan dan yang diperoleh dari pelatih Sepaktakraw SMP Negeri 2 Batang Anai diperoleh keterangan bahwa pemain Sepaktakraw SMP Negeri 2 Batang Anai sebagian besar belum maksimal pelaksanaan Sepak Sila dalam bermain Sepaktakraw baik sewaktu uji tanding maupun kompetisi.

Karena di sini terdapatnya beberapa faktor yang mempenggaruhi pada pemain dalam melaksanalan kemampuan Sepak Sila. Dalam melakukan Sepak Sila sangat diperlukan keseimbangan karena faktor keseimbangan merupakan kemampuan untuk mempertahankan sistem saraf otot tersebut dalam posisi atau sikap yang efisien selagi kita bergerak.

Kelincahan sangat penting dimiliki seseorang dalam melakukan Sepak Sila. Apabila seseorang memiliki kelincahan, maka akan mudah mengubah arah sesuai situasi melakukan Sepak Sila. Dalam permainan Sepak Sila faktor kekuatan sangat penting untuk meningkakan kemampuan otot untuk dapat mengatasi beban pada saat melakukan aktivitas tubuh.

Kelenturan juga sangat penting bagi seorang melakukan Sepak Sila karena dengan mempunyai kelenturan yang baik maka pada saat melakukan Sepak Sila akan mudah dilakukan oleh pemain sepaktakraw SMP Negeri 2 Batang Anai. Faktor koordinasi merupakan kemampuan seseorang untuk merangkai beberapa unsur gerak menjadi satu gerakan yang selaras dan sesuai dengan tujuannya.

Faktor daya tahan merupakan kemampuan seseorang melakukan intensitas sepaksila. Faktor kecepatan sangat di perlukan karena faktor kecepatan merupakan kemampuan seseorang mengarahkan semua sistemnya melawan beban jarak waktu yang menghasilkan kerja mekanik. 
Permainan Sepaktakraw di mainkan tanpa menggunakan tangan untuk memukul bola, bahkan tidak boleh menyentuh lengan. Bola hanya boleh menyentuh atau dimainkan dengan kaki, dada, paha, bahu dan kepala. Permainan Sepaktakraw diawali dengan sepak mula sebagai servis yang dilakukan oleh tekong. Sepak mula dilakukan oleh tekong atas lambungan bola oleh pelambung yang diarahkan ke tekong.

Tekong harus berada di dalam lingkaran yang telah disediakan. Begitu juga untuk tekong, pada waktu melakukan sepak mula salah satu kakinya harus tetap berada di dalam lingkaran tempat tekong melakukan sepak mula. Tekong harus mengarahkan bola ke daerah lawan melalui atas net (jaring). Dilain pihak lawan harus menerima bola dan mengembalikannya ke daerah lawan. Pihak lawan diberi kesempatan menyentuh bola sebanyak tiga kali.

\section{Sepak Sila}

Sepak Sila adalah suatu teknik dasar penting dan utama dalam permain Sepaktakraw, karena kemampuan penguasaan Sepak Sila yang baik akan memudahkan seseorang dalam mengontrol, mengumpan, menerima bola, dan menahan bola dari serangan lawan".

Dari kutipan di atas jelas bahwa di dalam menerima bola, memberikan umpan kepada smasher, menahan serangan lawan, dan menghadang atau menguasai bola lebih dominan mengunakan Sepak Sila. Dengan menguasai kemampuan Sepak Sila yang baik dan benar, maka kemampuan dalam melakukan Sepak Sila yang tepat dan benar akan terasa mudah dalam menyepak bola dengan efektif dan efesien, untuk itu perlu seorang pemain Sepaktakraw menguasai Sepak Sila yang baik.

Berdasarkan kutipan di atas dapat dilihat bahwa, dalam pelaksanakan Sepak Sila ada bebarapa hal teknik dasar yang harus dikuasai dalam permainan Sepaktakraw.

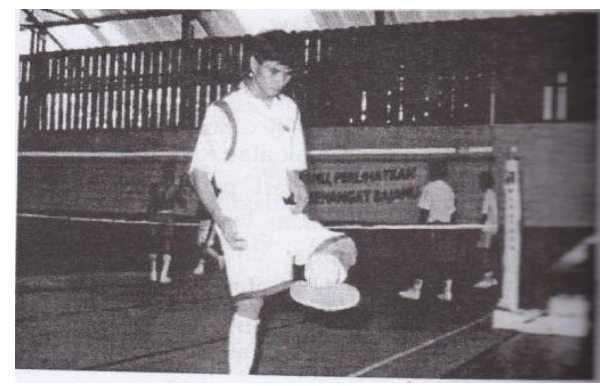

Gambar 1. Teknik pelaksanaan sepaksila, (Zalfendi,2009:118)

Untuk meningkatkan kemampuan Sepak Sila yang baik dan benar maka pemain yang latihan Sepaktakraw harus rutin mengulang melakukan latihan Sepak Sila setiap waktu, karena sulit bagi pemula kalau tidak mengulangi latihan tersebut.

\section{Keseimbangan}

Dalam pelaksanaan keterampilan gerak kasar diperlukan untuk memperhatikan posisi atau sikap tubuh, hal tersebut menunjukan keseimbangan.

Kemampuan tersebut menunjukan salah satu sifat dasar dalam olahraga dinamis yang membutuhkan perubahan mendadak dalam gerakan. Sebagai contoh: pemain yang baru saja melakukan Sepak Sila, berusaha untuk mendapatkan keseimbangan kembali.

Keseimbangan statis yaitu kemampuan untuk mempertahankan tubuh dalam kondisi bergerak atau selama melakukan gerakan. Keseimbangan adalah kemampuan yang digunakan untuk mengukur tingkat keseimbangan seseorang, seperti berdiri dengan satu kaki membentuk pesawat terbang. Dalam melakukan Sepak Sila keseimbangan sangat penting untuk mengontrol bola saat melakukan Sepak Sila. Karena itu keseimbangan sangat penting yang harus dimiliki oleh pemain Sepaktakraw.

\section{Kelincahan}

Kelincahan berasal dari kata lincah yang berarti gesit atau cekatan. Di dalam gerak yang gesit atau cekatan akan menyangkut koordinasi merangkaikan beberapa gerakan. Kelincahan merupakan salah satu kemampuan kondisi fisik yang sangat penting dalam kehidupan seharihari maupun dalam kegiatan olahraga. 
Kelincahan yang diteliti pada penelitian ini adalah kelincahan secara umum (General Agility). Baik tidaknya suatu kelincahan trgantung dari kekuatan kelompok otot di daerah tungkai dan kaki, kelentukan sendi di daerah anggota bawah, dan kemampuan merangkaikan beberapa gerkan menjadi satu gerakan yang berkesinambungan.

\section{METODE}

Jenis penelitian ini adalah korelasi. Penelitian ini bertujuan untuk mengetahui hubungan keseimbangan $\left(\mathrm{X}_{1}\right)$ dan kelincahan $\left(X_{2}\right)$ terhadap keterampilan Sepak Sila (Y) pemain Sepaktakraw SMP Negeri 2 Batang Anai.

Penelitian ini dilaksanakan di SMP Negeri 2 Batang Anai, sedangkan waktu penelitian ini akan dilaksanakan pada tanggal 16 Mei tahun 2014. Arikunto (1992:115) menyatakan populasi adalah keseluruhan subjek penelitian. Adapun subjek penelitian ini adalah keseluruan pemain Sepaktakraw yang mengikuti latihan Sepaktakraw di SMP Negei 2 Batang Anai yang berjumlah 15 orang.

Mengingat jumlah populasi relatif kecil, maka seluruh populasi di jadikan sampel sebanyak 15 orang, teknik pengambilan sampel yang digunakan yaitu dengan memakai teknik total sampling.

Berdasarkan jenis data yang digunakan dalam penelitian ini adalah data primer yaitu data yang langsung dikumpulkan oleh peneliti dari sumbernya yaitu sampel yang telah ditetapkan, kemudian data skunder juga didapat melalui informasi dari Guru/pelatih Sepaktakraw di SMP Negeri 2 Batang Anai, kondisi lapangan, sarana dan prasarana di sekolah.

Berdasarkan sumbernya, alat yang digunakan dalam penelitian ini didapatkan melalui tes langsung kepada responden dan sampel yang digunakan yaitu pemain Sepaktakraw SMP Negeri 2 Batang Anai.

Berhubungan data yang diperlukan dalam penelitian ini merupakan data primer maka pengambilan data dilakukan dengan cara melakukan tes, dan pengukuran terhadap (1) Tes Keseimbangan (2) Tes Kelincahan (3) Tes Sepak Sila. Penjelasan pelaksanaan ketiga tes ini adalah sebagai berikut:

1. Tes untuk keseimbangan a. Tujuan

Untuk mengukur tingkat keseimbangan seseorang dalam melakukan sesuatu gerakan. (Syahara, 2004:15).

b. Peralatan

1. Stopwatch

2. Buku/blangko tes

3. Pulpen

c. Pelaksanaaan tes

Testee berdiri dengan satu kaki (menggunakan kaki yang terkuat), selanjutnya kaki lain di lipat berbentuk sila diletakkan pada atas lutut penyangga dan membentangkan kedua tangan serata bahu seperti sayap pesawat terbang. Ketika ada abaaba, naikkan tumit dari lantai dan tetapkan keseimbangan selama mungkin tanpa menggerakkan bidang tumpu kaki dari posisi semula ataupun membiarkan tumit menyentuh lantai. Testee tidak diperkenankan menurunkan posisi kedua tangan yang terbentang selama tes berlangsung.

d. Penilaian

Skor diperoleh yaitu waktu terlama dari hitungan detik antara tumit dinaikkan dan keseimbangan hilang. Tes dilakukan 2 kali pengulangan, hanya waktu yang terlama yang di catat.

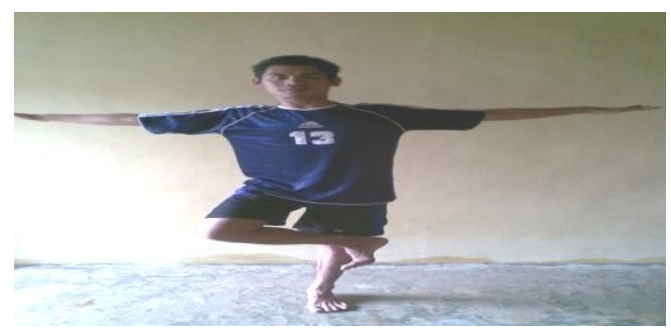


Gambar 3. Tes keseimbangan.(Syahara, 2004:1)

2. Tes kelincahan

a. Tujuan

Tes ini bertujuan untuk mengukur kelincahan dalam bergerak mengubah arah. Tingkat usia 9 tahun sampai mahasiswa (Winarno, 2006:9092)

b. Alat dan Perlengkapan

1) Stopwatch

2) Formulir dan alat tulis.

3) Petugas: Starter 1 orang, pengambil waktu menurut keperluan, pengawas 1 orang dan pencatat 1 orang.

4) Lapangan: Lintasan lari yang datar berjarak 10 meter dengan kedua ujungnya dibatasi oleh garis lurus. Pada kedua ujung lintasan dibuat setengah lingkaran dengan jari-jari $30 \mathrm{~cm}$, untuk tempat balok- balok (Gambar 4).

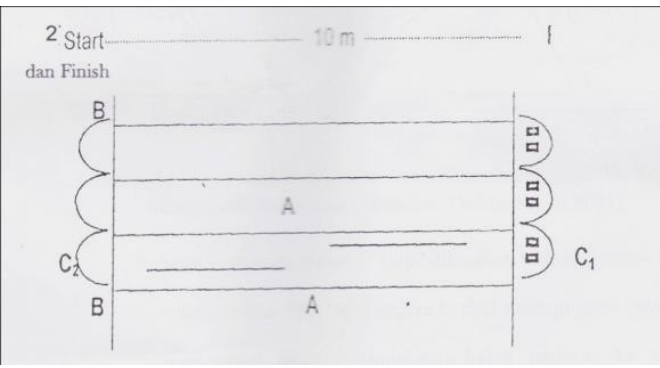

Gambar 4. Lintasan Shuttle Run Sumber: (Winarno, 2006:90)

Keterangan Gambar 4:

$\mathrm{A}=$ Lintasan lari

$\mathrm{B}=$ Garis Star dan Finish

C1 = Tempat Balok Kayu yang akan dipindahkan C2 = Tempat Balok Kayu yang akan dipindahkan $=$ Balok- balok Kayu

c. Prosedur pelaksanaan:
1. Start dilakukan dengan start berdiri, pada aba-aba "bersedia" testee dengan salah satu ujung jari kaki sedekat mungkin dengan garis star (Gambar 5a).

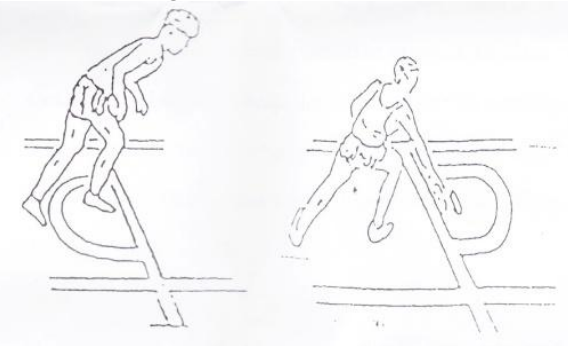

Gambar 5a.Testi Berdiri di Depan Garis Start dan Gambar 5b. Testee Mengambil Balok Kayu. Sumber : (Winarno, 2006:

91)

2. Setelah Tenang, aba-aba "siap" diberikan testee siap untuk berlari.

3. Pada aba- aba "Ya" testee segera berlarimenuju garis batas untuk mengambil dan memindahkan balok pertama ke setengah lingkaran yang berada di tempat garis star (Gambar $5 b)$.

4. Kemudian kembali lagi menuju garis batas untuk mengambil dan memindahkan balok kedua ketengah lingkaran yang berada ditempat garis start.

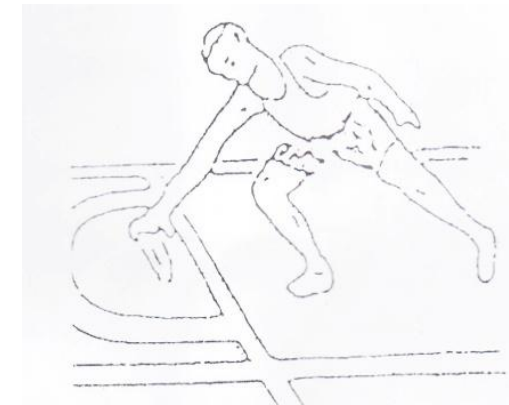

Gambar 6. Testee Meletakan Balok Kayu pada setengah Lingkaran

Sumber: (Winarno, 2006:92)

1. Bersamaan dengan aba-aba "Ya", stopwacth dijalankan dan dihentikan pada saat terakhir diletakan, stopwacth dihentikan. 
Catatan: Balok kayu dapat di ganti dengan benda lain yang mendekati ukuran balok kayu tersebut. Setiap testee diberikan kesempatan melakukan dua kali, balok harus diletakan tidak boleh dilemparkan dan balok diletakan di dalam setengah lingkaran.

\section{d. Pencatatan Hasil:}

1. Hasil dicatat adalah waktu yang dicapai oleh testee untuk $\begin{array}{llll}\text { menempuh jarak } & 4 & \mathrm{X} & 10\end{array}$ meter.

2. Waktu yang dicapai dihitung sampai persepuluh detik. Hasil kedua percobaan dicatat dan diambil yang terbaik.

3. Tes Kemampuan Sepaksila

b. Tujuan : Tes ini bertujuan mengukur kemampuan Sepak Sila

c. Peralatan :

1) Blangko tes menimang bola

2) Bola sebanyak 5 buah

3) StopWatch

4) Pulpen

d. Pelaksanaan :

1) Testee berdiri dengan memegang sebuah bola takraw

1) Setelah aba-aba "ya" segera melabungkan bola dan disepak dengan kaki bahagian dalam (sepak sila) lurus keatas setinggi kepala atau lebih secara berulang-ulang.

2) Jika bola tidak dapat dikuasai oleh testee maka boleh mengambil bola yang jatuh tadi.

e. Penilaian :

Skor diperoleh yaitu diberi waktu dalam 1 menit untuk melakukan timangbola sebanyak mungkin, tes ini dilakukan hanya satu kali. Yang dinilai dalam tes ini yaitu banyaknya bola yang disepak setinggi kepala atau lebih. Apabila bola yang disepak dibawah setinggi kepala maka skor tidak di hitung.

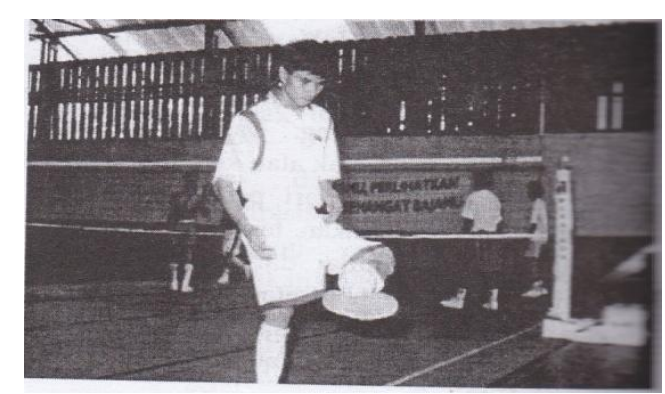

Gambar 7. Tes menimang bola (Zalfendi,2009:118)

Berdasarkan hipotesis yang diajukan, analisis data yang di lakukan dengan menggunakan statistik analisa korelasi product moment. Analisis korelasi digunakan untuk membuktikan penelitian yang diajukan, adapun rumus korelasi tersebut menggunakan rumus korelasi product moment oleh Person dalam Sudjana (1992:382).

$$
\begin{aligned}
& \text { Ry12 } \\
& =\sqrt{\frac{r^{2} y 1+r^{2} y_{2-2\left(r y_{1}\right)\left(r y_{2}\right)\left(r x_{12}\right)}}{1-\left(r y_{12}\right)^{2}}}
\end{aligned}
$$

\section{HASIL PENELITIAN}

Dalam bab ini akan disajikan hasil pengukuran Keseimbangan dan Kelincahan serta Keterampilan Sepak Sila pemain Sepaktakraw SMP Negeri 2 Batang Anai. Untuk lebih jelasnya masing-masing data dideskriptifkan sebagai berikut:

\section{Keseimbangan}

Pengukuran keseimbangan yang dilakukan terhadap sampel 15 pemain, dengan skor terbesar yakni 42.56 detik dan skor terkecil yakni 32.04 detik, dengan rata-rata (mean) keseimbangan siswa yakni 35.76 detik. Untuk lebih jelasnya dapat dilihat pada tabel berikut.

Tabel 1. 


\begin{tabular}{|c|c|c|c|}
\hline \multicolumn{4}{|c|}{$\begin{array}{c}\text { Didstribusi Frekuensi Data } \\
\text { Keseimbangan }\left(\mathbf{X}_{1}\right)\end{array}$} \\
\hline \multirow{2}{*}{ No } & \multirow{2}{*}{ Kelas Interval } & Frekuensi & \multirow[b]{2}{*}{ Relatif } \\
\hline & & Absolut & \\
\hline 1 & $32.04-34.20$ & 7 & $46.67 \%$ \\
\hline 2 & $34.21-36.37$ & 4 & $26.67 \%$ \\
\hline 3 & $36.38-38.54$ & 1 & $6.67 \%$ \\
\hline 4 & $38.55-40.71$ & 1 & $6.67 \%$ \\
\hline 5 & $40.78-42.88$ & 2 & $13.33 \%$ \\
\hline$\Sigma$ & 15 & $100.00 \%$ & \\
\hline
\end{tabular}

Berdasarkan pada tabel distribusi frekuensi di atas dari 15 pemain yang dijadikan sampel, 7 pemain $(46.67 \%)$ memiliki keseimbangan dari $32.04-34.20$ detik, 4 pemain $(26.67 \%)$ memiliki keseimbangan dari 34.21 - 36.37 detik, 1 pemain $(6.67 \%)$ memiliki keseimbangan dari 36.38 - 38.54 detik, 1 pemain $(6.67 \% \%)$ memiliki keseimbangan dari 38.55 - 40.71 detik, dan 2 pemain (13.33\%) memiliki keseimbangan dari 40.78 - 42. 88 detik. Untuk lebih jelasnya data keseimbangan juga bisa dilihat pada histogram ini.

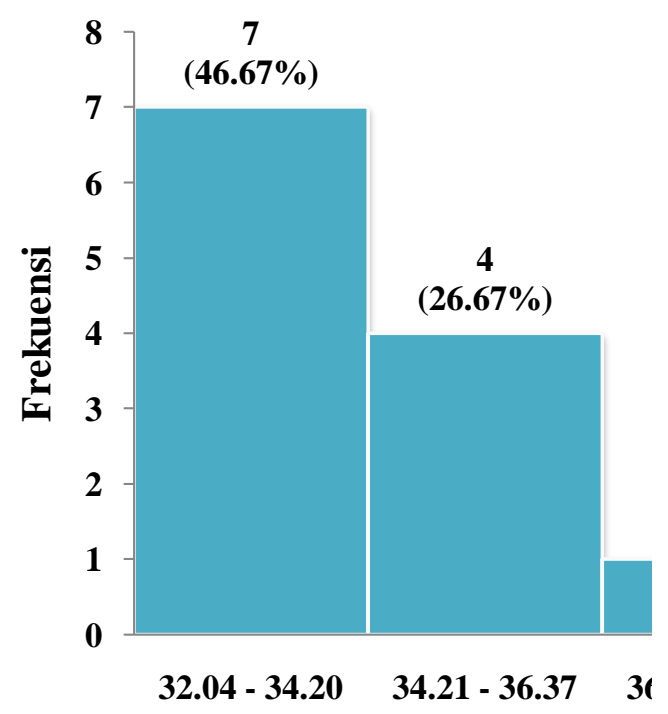

Gambar 8. Histogram Data Keseimbangan

\section{Kelincahan}

$$
\left(\mathrm{X}_{1}\right)
$$

Pengukuan kelincahan yang dilakukan terhadap sampel 15 pemain. Didapat skor tertinggi yakni 12.85 detik dan skor terendah yakni 10.98 detik, dengan rata-rata (mean) kelincahan siswa yakni 11.83 detik. Selebaran data selengkapnya dapat dilihat pada tabel berikut:

Tabel 2.

Distribusi Frekuensi Data Kelincahan

\begin{tabular}{|c|c|c|c|}
\multicolumn{2}{|c}{$\left(\mathbf{X}_{\mathbf{2}}\right)$} \\
\cline { 3 - 3 } No & \multirow{2}{*}{ Kelas Interval } & Frekuensi & \multirow{2}{*}{} \\
\cline { 3 - 3 } & & Absolut & \multirow{2}{*}{ Relatif } \\
\hline 1 & $10.98-11.36$ & 3 & 20.00 \\
\hline 2 & $11.37-11.75$ & 4 & 26.67 \\
\hline 3 & $11.76-12.14$ & 5 & 33.33 \\
\hline 4 & $12.15-12.53$ & 1 & 6.67 \\
\hline 5 & $12.54-12.92$ & 2 & 13.33 \\
\hline$\sum$ & $\mathbf{1 5}$ & $\mathbf{1 0 0 . 0 0}$ & \multicolumn{2}{|c}{} \\
\cline { 1 - 3 } & &
\end{tabular}

Berdasarkan pada tabel distribusi frekuensi di atas dari 15 pemain yang dijadikan sampel, 3 pemain $(20.00 \%)$ memilki kelincahan dari 10.98 - 11.36 detik, 4 pemain $(26.67 \%)$ memilki kelincahan dari 11.37 - 11.75 detik, 5 pemain $(33.33 \%)$ memilki kelincahan dari 11.76 - 12.14 detik, 1 siswa (6.67\%) memilki 12.15 12.53 detik, dan 2 pemain (13.33\%) memilki kelincahan dari 12.54 12.92 detik. Untuk lebih jelasnya data kelincahan juga bisa dilihat pada histogram ini.

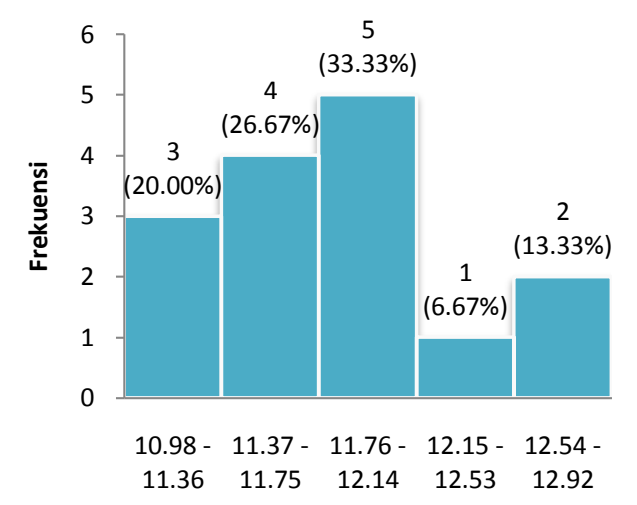

Gambar 9. Histogram Data Kelincahan $\left(\mathrm{X}_{2}\right)$ 


\section{Keterampilan Sepak Sila Sepaktakraw}

Dari hasil tes keterampilan Sepak Sila Sepaktakraw didapat skor yang tertinggi yakni 46 kali dan skor terendah yakni 20 kali, dengan rata-rata (mean) keterampilan Sepak Sila pemain yakni 32.67 kali. Untuk lebih jelas sebaran data selengkapnya dapat dilihat pada tabel berikut:

Tabel 3.

Distribusi Frekuensi Data Keterampilan Sepak Sila (Y)

\begin{tabular}{|c|c|c|c|}
\hline \multirow{2}{*}{ No } & \multirow{2}{*}{ Kelas Interval } & Frekuensi & \multirow{2}{*}{} \\
\cline { 3 - 3 } & & Absolut & \multirow{2}{*}{ Relatif } \\
\hline 1 & $20-25$ & 3 & 20.00 \\
\hline 2 & $26-31$ & 5 & 33.33 \\
\hline 3 & $32-37$ & 1 & 6.67 \\
\hline 4 & $38-43$ & 4 & 26.67 \\
\hline 5 & $44-49$ & 2 & 13.33 \\
\hline$\sum$ & $\mathbf{1 5}$ & $\mathbf{1 0 0 . 0 0}$ & \multicolumn{2}{|c}{} \\
\hline
\end{tabular}

Berdasarkan pada tabel distribusi frekuensi di atas dari 15 pemain yang dijadikan sampel, 3 pemain $(20.00 \%)$ memiliki keterampilan sepaksila dari $20-25$ kali, 5 pemain $(33.33 \%)$ memiliki keterampilan sepaksila dari $26-31$, 1 pemain $(6.67 \%)$ memiliki keterampilan sepaksila dari $32-37$ kali, 4 pemain $(26.67 \%)$ memiliki keterampilan sepaksila dari $38-43$ kali, dan 2 pemain (13.33\%) memiliki keterampilan sepaksila dari 44 - 49 kali. Untuk lebih jelasnya data keterampilan sepaksila bisa dilihat pada histogram ini.

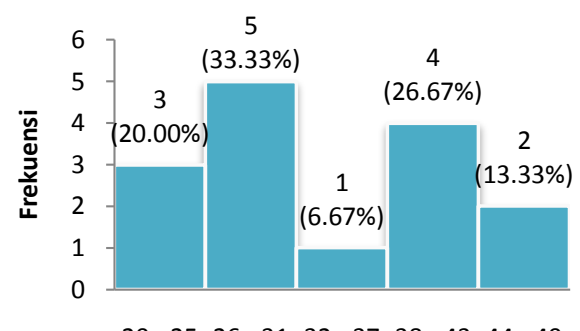

Gambar 10. Histogram Data Keterampilan Sepak Sila (Y)

\section{A. Analisa Data}

\section{Uji Persyaratan Analisis}

Seperti yang dijelaskan pada bab sebelumnya sebelum melakukan pengujian hipotesis tentang hubungan antara variabel bebas dengan variabel terikat terlebih dahulu dilakukan uji persyaratan analisis, yaitu uji normalitas dengan uji Lilliefors.

\section{a. Uji Normalitas}

Hasil analisis uji normalitas sebaran data masing-masing variabel disajikan dalam tabel berikut ini:

\section{Tabel 4.}

\section{Rangkuman Uji Normalitas dengan Uji} Liliefors

\begin{tabular}{|c|c|c|c|c|c|}
\hline $\begin{array}{l}\mathbf{N} \\
\mathbf{0}\end{array}$ & $\begin{array}{c}\text { Variab } \\
\text { el }\end{array}$ & $\mathbf{N}$ & Lo & $\begin{array}{c}\mathbf{L}_{\text {ta }} \\
\text { bel }\end{array}$ & $\begin{array}{l}\text { Distr } \\
\text { ibusi }\end{array}$ \\
\hline 1 & $\begin{array}{c}\text { Keseim } \\
\text { bangan } \\
\left(\mathrm{X}_{1}\right)\end{array}$ & $\begin{array}{l}1 \\
5\end{array}$ & $\begin{array}{c}0 . \\
18 \\
6\end{array}$ & $\begin{array}{c}0 . \\
22 \\
0\end{array}$ & $\begin{array}{l}\text { Nor } \\
\text { mal }\end{array}$ \\
\hline 2 & $\begin{array}{c}\text { Kelinca } \\
\text { han } \\
\left(\mathrm{X}_{2}\right)\end{array}$ & $\begin{array}{l}1 \\
5\end{array}$ & $\begin{array}{c}0 . \\
27 \\
9\end{array}$ & $\begin{array}{c}0 . \\
22 \\
0\end{array}$ & $\begin{array}{c}\text { Tida } \\
\text { k } \\
\text { Nor } \\
\text { mal }\end{array}$ \\
\hline 3 & $\begin{array}{c}\text { Ketera } \\
\text { mpilan } \\
\text { Sepak } \\
\text { Sila } \\
\text { Sepakta } \\
\text { kraw } \\
\text { (Y) }\end{array}$ & $\begin{array}{l}1 \\
5\end{array}$ & $\begin{array}{c}0 . \\
19 \\
6\end{array}$ & $\begin{array}{c}0 . \\
22 \\
0\end{array}$ & $\begin{array}{l}\text { Nor } \\
\text { mal }\end{array}$ \\
\hline
\end{tabular}

Tabel di atas menunjukan hasil normalitas dari ke tiga variabel dengan kriteria jika Lo lebih besar dari $\mathrm{L}_{\text {tabel }}$ berarti populasi berdistribusi tidak normal, sebaliknya jika Lo lebih kecil atau sama dengan $\mathrm{L}_{\text {tabel }}$ berarti populasi berdistribusi normal. Untuk hasil pengujian Keseimbangan $\left(\mathrm{X}_{1}\right)$ skor Lo $=0.186$ 
dengan $\mathrm{n}=15$, sedangkan $\mathrm{L}_{\text {tabel }}$ pada taraf pengujian signifikan $\alpha=0.05$ diperoleh 0.220 , sehingga disimpulkan bahwa skor keseimbangan berdistribusi normal (untuk lebih jelasnya dapat dilihat pada lampiran $2)$.

Untuk hasil pengujian Kelincahan $\left(\mathrm{X}_{2}\right)$ skor Lo $=0.279$ dengan $\mathrm{n}=15$, sedangkan $\mathrm{L}_{\text {tabel }}$ pada taraf pengujian signifikan $\alpha=0.05$ diperoleh 0.220 , sehingga disimpulkan bahwa skor kelincahan berdistribusi tidak normal (untuk lebih jelasnya dapat dilihat pada lampiran 3).

Untuk hasil Keterampilan Sepak Sila Sepaktakraw (Y) skor Lo $=0.196$ dengan $\mathrm{n}=15$, sedangkan $\mathrm{L}_{\text {tabel }}$ pada taraf pengujian signifikan $\alpha=0.05$ diperoleh 0.220 , sehingga disimpulkan bahwa skor Keterampilan Sepak Sila Sepaktakraw berdistribusi normal (untuk lebih jelasnya dapat dilihat pada lampiran 4).

\section{Uji Hipotesis}

a. Uji Hipotesis Satu (Terdapat Hubungan Signifikan Antara Keseimbangan Keterampilan Sepak Sila Sepaktakraw). yang signifikan antara Keseimbangan $\left(\mathrm{X}_{1}\right)$ dengan Keterampilan Sepak Sila Sepaktakraw (Y).

\section{b. Uji Hipotesis Dua (Tidak Terdapat Hubungan Yang Signifikan Antara Kelincahan dengan Keterampilan Sepak Sila Sepaktakraw)}

Dengan $\alpha=0.05$ dan dk n (15) $-2=$ 13 , diperoleh nilai $t_{\text {tabel }}=1.771$. Kriteria pengujian adalah: Jika $t_{\text {hitung }}>t_{\text {tabel }}$ Ho yang menyatakan tidak terdapat hubungan antara variabel ditolak berarti terdapat hubungan yang signifikan, sebaliknya jika $t_{\text {hitung }}<t_{\text {tabel }}$ Ho diterima sehingga tidak terdapat hubungan. Berdasarkan hasil perhitungan di atas di dapat $t_{\text {hitung }}(0.371)$ $<t_{\text {tabel }}(1.771)$ dan $r=0.102$. Maka dapat diambil kesimpulan tidak terdapat hubungan antara Kelincahan $\left(\mathrm{X}_{2}\right)$ dengan Keterampilan Sepak Sila Sepaktakraw (Y).

\section{c. Uji Hipotesis Tiga (Terdapat Hubungan Yang signifikan Keseimbangan dan Kelincahan Secara Bersama-sama Terhadap Keterampilan Sepak Sila Sepaktakraw)}

Tabel 5.

Rangkuman Hasil Analisis Korelasi Sederhana $X_{1}$ dan $Y$

\begin{tabular}{|c|c|c|c|c|c|c|c|}
\hline Variabel & $\mathbf{N}$ & hitung & $\mathbf{r}^{2}$ & $\mathbf{t}_{\text {bit }}$ & $\mathbf{A}$ & $t_{\text {tabe }}$ & angimbangan dan \\
\hline $\begin{array}{l}\text { Keseimbangan } \\
\left(\mathrm{X}_{1}\right) \text { dan } \\
\text { Keterampilan } \\
\text { Sepaksila } \\
\text { Sepak Takraw } \\
(\mathrm{Y})\end{array}$ & 15 & 0.668 & 0.447 & 3.240 & 0.05 & 1.771 & $\begin{array}{l}\text { Signifferarsama-sama terhadap Keterampilan } \\
\text { Sepak Sila Sepaktakraw dilakukan analisis } \\
\text { korelasi ganda dan memberi gambaran } \\
\text { sebagai berikut: } \\
\\
\text { Tabel } 7 .\end{array}$ \\
\hline
\end{tabular}

Rangkuman Hasil Analisis

Dengan $\alpha=0.05$ dan dk n (15) $-2=$ Korelasi Ganda $X_{1}, X_{2}$, dan $Y$

\begin{tabular}{|c|c|c|c|c|}
\hline 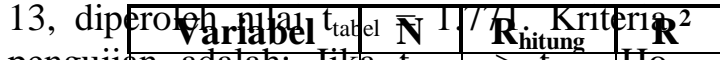 & $\mathbf{F}_{\text {hitung }}$ & $\alpha$ & $\mathbf{F}_{\text {tabel }}$ & Hubungan \\
\hline 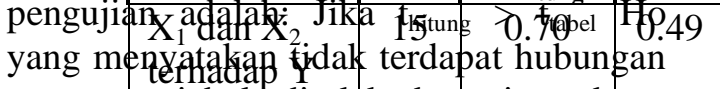 & 5.85 & 0.05 & 3.88 & Signifikan \\
\hline
\end{tabular}
antara variabel ditolak berarti terdapat hubungan yang signifikan, sebaliknya jika $t_{\text {hitung }}<t_{\text {tabel }}$ Ho diterima sehingga tidak terdapat hubungan. Berdasarkan hasil perhitungan diatas di dapat $t_{\text {hitung }}(3.240)>$ $t_{\text {tabel }}(1.771)$ dan $r=0.668$. Maka dapat diambil kesimpulan terdapat hubungan
Dengan menggunakan $\mathrm{k}=2$ sebagai pembilang dan (n-k-1) = 12 sebagai penyebut lalu $\alpha=0.05$ maka didapat nilai $=3.88$. Dari hasil analisa data didapat $\mathrm{F}_{\text {hitung }}(5.85)>\mathrm{F}_{\text {tabel }}(3.88)$, maka Ho ditolak dan Ha diterima. Terdapat 
hubungan yang signifikan antara Keseimbangan dan Kelincahan secara bersama-sama terhadap Keterampilan Sepaksila Sepak Takraw dengan $\mathrm{R}=0.70$.

\section{B. Pembahasan}

Berdasarkan hasil analisa data yang diperoleh dari penelian maka di dapat hasil dan kesimpulan sebagai berikut:

\section{Terdapat Hubungan Yang} Signifikan Antara Keseimbangan Terhadap Keterampilan Sepak Sila Pemain Sepaktakraw SMP Negeri 2 Batang Anai.

Dari hasil analilisis Keseimbangan $\left(\mathrm{X}_{1}\right)$ mempunyai hubungan terhadap Keterampilan Sepak Sila Pemain Sepaktakraw SMP Negeri 2 Batang Anai, ini dibuktikan dengan $r_{\text {hitung }} X_{1}=0.668$. Pada proses perhitungan diatas dapat dilihat terdapat hubungan yang signifikan hal ini dilihat dengan $t_{\text {hitung }}(3.240)>t_{\text {tabel }}$ (1.771).

Bedasarkan hasil penelitian di atas, sesuai pengertiannya "Sepak Sila adalah menyepak dengan kaki bagian dalam yang digunakan untuk menerima bola, menimbang (menguasai bola), mengumpan dan antaran bola, menyelamatkan serangan lawan" (Zalfendi, 2009:2) dan "Keseimbangan adalah mudahnya orang untuk mengontrol dan mempertahankan posisi tubuh (Harsono, 1988:223).

Ini menegaskan bahwa Keseimbangan sangat erat kaitannya dengan keterampilan Sepak Sila dalam Sepaktakraw, karena dengan keseimbangan pemain Sepaktakraw akan mudah melakukan Sepak Sila dan memainkan/menimang bola Takraw dengan lama. Dengan keseimbangan yang baik maka pemain Sepaktakraw SMP Negeri 2 Batang Anai menghasilkan Keterampilan Sepak Sila dalam Sepaktakraw yang baik pula. Dan dalam hal ini adalah keseimbangan dari kaki tumpuan disaat melakukan Sepak Sila dalam Sepaktakraw.

2. Tidak Terdapat Hubungan Yang Signifikan Antara Kelincahan Terhadap Keterampilan Sepak Sila Pemain Sepaktakraw SMP Negeri 2 Batang Anai

Dari hasil analilisis Kelincahan $\left(\mathrm{X}_{2}\right)$ tidak mempunyai hubungan yang signifikan terhadap Keterampilan Sepak Sila Pemain Sepaktakraw SMP Negeri 2 Batang Anai, hal ini dibuktikan dengan r hitung $\mathrm{X}_{2}=0.102$. Pada proses perhitungan di atas dapat dilihat tidak terdapat hubungan yang signifikan hal ini dilihat dengan $\mathrm{t}_{\text {hitung }}(0.371)<\mathrm{t}_{\text {tabel }}(1.771)$.

Hal ini mengungkapkan sesuai dengan pendapat Wilmore dalam Lusy Soviana (2012:10) menyatakan bahwa "kelincahan adalah kemampuan seseorang untuk dapat mengubah arah dengan cepat dan tepat pada waktu bergerak tanpa kehilangan keseimbangan". Sementara itu Sepak

Sila sendiri adalah "menyepak dengan kaki bagian dalam yang digunakan untuk menerima bola, menimbang (menguasai bola), mengumpan dan antaran bola, menyelamatkan serangan lawan" (Zalfendi, 2009:2). Berdasarkan kutipan di atas tadi, jelas terlihat bahwa tidak terdapat hubungan yang signifikan antara Kelincahan dengan Keterampilan Sepak Sila Sepaktakraw, karena Sepak Sila sesuai dengan pengertian yang dikemukakan sebelumnya yaitu menendang bola dengan kaki bagian dalam dan arah jalan bola lurus ke atas kepala. Semakin lurus arah bola semakin baik Sepak Sila seseorang. Oleh karena itu Kelincahan tidak memiliki hubungan yang signifikan antara Ketarampilan Sepak Sila Sepaktakraw.

3. Terdapat Hubungan Yang Signifikan Antara Keseimbangan dan Kelincahan Secara Bersamasama Terhadap Keterampilan Sepak Sila Pemain Sepaktakraw SMP Negeri 2 Batang Anai 
Berdasarkan hasil perhitungan korelasi linier ganda uji $\mathrm{F}$, di dapat $\mathrm{F}_{\text {hitung }}$ (5.85) > $\mathrm{F}_{\text {tabel }}$ (3.88) yang diperoleh dengan menggunakan rumus $\{\mathrm{N}-\mathrm{K}-1\}$ $15-2-1=12$ pada $\alpha=0,05$. Ini menunjukan bahwa Keseimbangan dan Kelincahan secara bersama-sama memberikan hubungan terhadap Keterampilan Sepak Sila Pemain Sepaktakraw SMP Negeri 2 Batang Anai.

Jadi berdasarkan pembahasan di atas maka keterampilan Sepak Sila pemain Sepaktakraw dilakukan tidak lepas dari keseimbangan dan kelincahan. Semakin baik keseimbangan dan kelincahan para pemain, maka keterampilan Sepak Sila dalam Sepaktakraw akan semakin baik sehingga prestasi pemain Sepaktakraw juga lebih maksimal.

Menurut perhitungan skor yang diperoleh, maka keseimbangan dan kelincahan akan mempengaruhi prestasi pemain dalam Sepaktakraw. Bila keseimbangan atlet baik maka dapat menahan dan mengontrol bola dari kawan maupun lawan main dengan baik dan bila kelincahan pemain Sepaktakraw baik maka dapat mengejar arah bola yang tentunya belum pasti ke mana arah larinya artinya kelincahan yang dimiliki pemain akan manfaatkan oleh pemain itu sendiri dalam mengejar arah bola.

\section{KESIMPULAN}

Berdasarkan hasil penelitian dan pengujian hipotesis maka dapat ditarik kesimpulan sebagai berikut:

1. Terdapat hubungan yang signifikan antara Keseimbangan terhadap Keterampilan Sepak Sila Pemain Sepaktakraw SMP Negeri 2 Batang Anai dengan $t_{\text {hitung }}$ (3.240) $>t_{\text {tabel }}$ (1.771).

2. Tidak terdapat hubungan yang signifikan antara Kelincahan terhadap Keterampilan Sepak Sila Pemain Sepaktakraw SMP Negeri 2 Batang Anai dengan $t_{\text {hitung }}(0.371)<t_{\text {tabel }}$ (1.771).
3. Terdapat hubungan yang signifikan antara Keseimbangan dan Kelincahan secara bersama-sama terhadap Keterampilan Sepak Sila Pemain Sepaktakraw SMP Negeri 2 Batang Anai dengan $\mathrm{F}_{\text {hitung }}(5.86)>\mathrm{F}_{\text {tabel }}(3.88)$.

Diharapkan dapat membantu mengatasi masalah yang ditemui dalam pelaksanaan keterampilan Sepak Sila pemain Sepaktakraw, diantaranya:

1. Untuk pembina diharapkan melakukan pembinaan keterampilan Sepak Sila dengan baik karena ini merupakan teknik dasar yang utama dalam permainan Spaktakraw.

2. Para pelatih disarankan untuk tidak mengabaikan keseimbangan dan kelincahan dalam meningkatkan keterampilan Sepak Sila dalam Sepaktakraw dengan melakukan latihan secara terprogram dan sistematis.

3. Untuk para atlet, agar dapa1 meningkatkan keterampilan Sepak Silanya perlu adanya latihan khusus untuk meningkatkan keseimbangan dan kelincahan.

4. Untuk para peneliti, penelitian ini hanya terbatas pada atlet/pemain Sepaktakraw yang mengikuti kegiatan pengembangan yang di adakan di sekolah, untuk itu kepada peneliti yang lain perlu diadakan penelitian pada sampel dan populasi yang lebih besar lagi.

\section{DAFTAR PUSTAKA}

Arikunto, Suharismi.(1992). Prosedur Penelitian. Yogyakarta : Renika Cipta.

B, Asril. (1994). Teknik Khusus Dalam Permainan Sepaktakraw. Padang: FPOK IKIP Padang.

Darwis, Ratinus. (1992). Olahraga Pilihan Sepaktakraw. PPTK Jakarta: Dirjen Dikti Depdikbud. 
Hamdani. (2003). Sumbangan Keseimbangan dan Persepsi Kinestik Kepada Hasil Sepak Sila. Surabaya : Skripsi Unesa Surabaya.

Harsono. (1988). Penuntun Pelatih dan Permainan Sepaktakraw. Jakarta: Depdikbud.

Lusy, Soviana. (2012). Hubungan Kelincahan dengan Keterampilan Menggiring Bola Pemain Sepakbola Siswa SD Negeri 17 Batang Anai Padang Pariaman. Padang: Skripsi UNP.

Nurhasan. (1986). Tes dan Pengukuran. Jakarta: universitas terbuka Jakarta.

Sajoto. (1988). Pembinaan Kondisi fisik Dalam Olahraga. Jakarta: Depdikbud Dirjen Dikti $\mathrm{T} 2$ LPTK.

Sudjana. (1992). Metode Statistik. Bandung: Tarsio, Bandung.

Syahara, Sayuti. (2004). Senam Dasar. Padang: Universitas Negeri Padang.

Undang-undang RI No 03.(2005). Sistem Keolahragaan Nasional. Yogyakarta: Pustaka Yudisti.

UNP. (2010). Pedoman Akademik Mahasiswa. Universitas Negeri Padang.

Winarno. (2006). Tes Keterampilan Olahraga. Penerbit: Laboratorium Ilmu Keolahragaan, Malang: FIP.

Yusuf, Ucup, dkk. (2001). Pengaruh Pembelajaran Servis dan Koordinasi Mata Kaki Terhadap Hasil Belajar Servis Sepaktakraw Pada Siswa Putra Kelas VIII $\begin{array}{lll}\text { SMPN } & \text { III } & \text { Sukoharjo }\end{array}$
TP.2008/2009 Skripsi Roni Wahyu Utomo."

http://eprints.uns.ac.id/5180/1/171 381312201008511.pdf Rabu, 5 Februari 2014. 20.30

Zaidul. (2005). Permaian Sepak Takraw. Diknas Padang

Zalfendi, dkk. (2009). Pengantar Latihan dan Pendidikan Sepaktakraw. Padang: FIK UNP. 